\title{
Colorectal Mutant Cancer Protein
}

National Cancer Institute

\section{Source}

National Cancer Institute. Colorectal Mutant Cancer Protein. NCI Thesaurus. Code

C17514.

Colorectal mutant cancer protein ( $829 \mathrm{aa}, \sim 93 \mathrm{kDa}$ ) is encoded by the human MCC gene.

This protein may be involved in modulation of the cell cycle. 